\title{
PLUTARCH, PLATO AND SPARTA
}

\section{Futter (University of the Witwatersrand)}

In the Life of Lycurgus, Plutarch appears to say that Plato embraced the Spartan constitution as a socio-political ideal. This claim generates a puzzle. On the one hand, the Republic's preferred form of government, a meritocratic aristocracy, is incompatible with the 'mixed' Spartan constitution, which balances power between different organs of state; on the other, the ardent Platonist Plutarch cannot reasonably be thought to have misunderstood the fundamentals of his teacher's political philosophy. This paper explores possible resolutions of the antinomy. It is concluded that while the Platonic republic can be regarded as an extension and idealisation of Spartan socio-economic arrangements, the cities' formal governmental structures are irreconcilable. Plutarch's attribution of the Spartan constitution to Plato is not strictly correct; the question of whether its assertion can be explained in terms of literary and rhetorical goals is left for future research.

In the Life of Lycurgus, Plutarch represents Sparta as an ideal polity. This may seem a surprising view of a notoriously repressive regime which brutalised its helot slave class. ${ }^{1}$ Not so, according to Plutarch: the exemplariness of the Lycurgan constitution was widely acknowledged amongst ancient philosophers:

[Lycurgus'] design for a civil polity was adopted by Plato, Diogenes, Zeno, and by all of those who have won approval for their treatises on the subject ... (31.2)

This claim is bound to strike the reader as questionable. When restricted to Plato, ${ }^{3}$ the glaring difficulty is that the Republic's preferred form of government, a

1 The Spartan treatment of the helots was considered objectionable even in antiquity. See e.g. Plato, Laws 776c; Thuc. 4.80.3.

2 The translation is by Bernadotte Perrin from the Loeb editions of the Lives. The rendering of ' $\pi 0 \lambda v \tau \varepsilon i ́ \alpha$ ' as 'civil polity' is discussed in §II below.

3 A dearth of textual evidence hinders evaluation of the claim in regard to Diogenes and Zeno. For discussion see e.g. Chroust 1965, Moles 2000 and Schofield 2000. 
meritocratic aristocracy (544e), is incompatible with the 'mixed' Lycurgan constitution, which balances power between different organs of state. ${ }^{4}$

Plutarch cannot reasonably be thought to have misunderstood the fundamentals of Plato's political philosophy. But how then are we to explain his assertion of what appears to be a manifest untruth? Two possible strategies for resolution are apparent. The first is to attempt a reinterpretation of the questionable claim so that it comes out true or justified; the second is to say that while the claim is not strictly true, its assertion is explicable in terms of literary and rhetorical goals. In the Alexander, Plutarch distinguishes the genres of history and biography (Alex. 1.2) and expresses the desire to influence his readers ethically by setting up models of virtuous character (Maxime, 776c-d). ${ }^{5}$ Conceivably this could be done by the use of a 'noble falsehood' (Rep. 414b-c). This paper will explore the first alternative, viz. truthful reinterpretation.

\section{II}

A first reading of Lyc. 31.2 straightforwardly identifies Plato's Republic with Lycurgus' Sparta. Plutarch's claim is that Plato's ideal polis and Lycurgan Sparta share a common constitution or form of government. ${ }^{6}$ Since this interpretation is subject to a serious difficulty, viz. the apparent incompatibility of the mixed Spartan government with the unmixed Platonic ideal, it makes sense to look for an alternative.

The first reading assumes that Plutarch is referring to the preferred constitution of Plato's Republic rather than his Laws. Although the focus on an ideal political order makes this is a plausible view, ${ }^{7}$ it is by no means certain. One reason for doubt is that the Republic characterises the Laconian as one of the four defective constitutions (544a1-3, c2-3), a city loving honour and victory (545a) rather than wisdom. Another is that Laws can be read as offering a practical utopia' (Moore 2012:82) compatible with the idealism of the Lycurgus. A more important point is that a reading of 'Plato's constitution' as referring to the Laws

4 In Plato's Laws the Athenian stranger describes the Spartan government as a 'mixture of elements' (691d-692c). So too Aristotle: 'But the defining principle of a good mixture of democracy and oligarchy is when it is possible to speak of the same constitution both as an oligarchy and as a democracy ... This is precisely how it is with the Spartan constitution' (Pol. 1294b13-19).

5 See Wardman 1974 on the genre of the Lives and its relation to history and encomium.

6 This fundamental identity is presupposed by Plutarch's additional claim that Plato's constitutional design was based on a Spartan model.

7 It is also the accepted reading in the scholarship. See e.g. Stadter 1999:476 and Liebert 2009:253. 
dissolves the problem of incompatible governmental organisation. In Magnesia, like Sparta, political power is shared between a number of different offices including assembly, council and magistrates. And this reading is not in any way ad hoc: Plutarch exhibits a deep familiarity with the Laws and appears to accept its account of Lycurgus' governmental reforms (Laws 691e-692a; Lyc. 5.6, 7.1; cf. Lyc. 28.1 and Laws 633b). ${ }^{8}$

In spite of its advantages, the proposal that Plutarch means to refer to the constitution of the Laws rather than the Republic is difficult to sustain. On the one hand, the objection that the Republic treats Sparta as an inferior constitution is easily answered. Plutarch would read these as criticisms of a corrupted Spartan regime which had departed from Lycurgus' laws (Lyc. 29.6; 30.1-2). ${ }^{9}$ On the other, although Magnesia's mixed constitution is more easily matched with the Spartan form of government, the Athenian Stranger describes it as a 'second best' political arrangement (Laws 739a3-740c3). It seems highly doubtful that Plutarch would support Lycurgus' credentials as a law-giver by claiming that Plato regarded his city as embodying a second-best constitution. For these reasons, we should provisionally conclude that Plutarch has the Republic in mind when he attributes the Lycurgan $\pi 0 \lambda ı \tau \varepsilon i ́ \alpha$ to Plato. ${ }^{10}$

On the first reading of Lyc. 31.2, Plutarch says that the Platonic and Lycurgan constitutions are identical, sharing a common constitution or governmental form. Is this the correct understanding of the Greek?

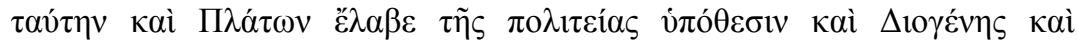

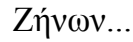

One reason for answering in the negative is that the word 'vं $\pi$ ' $\theta \varepsilon \sigma 1 \varsigma$ ' need not mean 'complete design'; it can also mean 'provisional model' or 'template'. When the Socrates of the Republic says that dialectic is the only method journeying beyond $\dot{\tau} \pi \circ \theta \dot{\varepsilon} \sigma \varepsilon 1 \varsigma$ by destroying them $(533 \mathrm{c} 8)$, he treats these as provisional items, images of intelligible originals (cf. $511 \mathrm{~b} f f$.). On this account of 'vं $\pi$ ó $\theta \varepsilon \sigma 1 \varsigma$ ', Plutarch's point may be that Plato's ideal city is based on a Spartan template. ${ }^{11}$ This

See also Tigerstedt 1974:234-236.

For discussion, see Stadter 1999:482-483.

10 My argument here depends on the view that the constitutions of the Laws and Republic are incompatible with one another. This seems to be the majority view in the contemporary scholarship (e.g. Bobonich 2002). However, if Plutarch holds that the two constitutions as substantially the same, the present inquiry will be unaffected. Any argument for compatibility will have to show that the government of the Laws is an aristocracy: the view that the Republic offers a mixed constitution is untenable.

11 Cf. Liebert's reading of $L y c$. 31.2: 'Plutarch claims that Lycurgus's Sparta is an early draft of Plato's Republic' (2009:253). Liebert translates 'v́mó $\theta \varepsilon \sigma 1 \zeta$ ' as 'model' (ibid.). 
reading is much weaker than the claim of common design; it is compatible with and may even require divergence between the two constitutions. If Plato's city is a 'projection' from or extension of Lycurgus' $\pi \mathrm{o} \lambda \imath \tau \varepsilon i$, it will not be the same as its model.

The interpretation of ' $\pi \mathrm{o} \lambda \iota \tau \varepsilon i ́ \alpha$ ' as 'organisation of government' can also be questioned (cf. Aristotle, Pol. 1278b, 1289a). The problem is that this reading of ' $\pi$ o $\lambda \iota \tau \varepsilon i ́ \alpha$ ' fails to make sense of the context in which Plutarch's problematic attribution occurs:

It was not, however, the chief design of Lycurgus then to leave his city in command over a great many others, but he thought that the happiness of an entire city, like that of a single individual, depended on the prevalence of virtue and concord within its own borders. The aim, therefore, of his arrangements and adjustments was to make his people free minded, selfsufficing, and moderate in all their ways, and to keep them so as long as possible. His design for a civil polity was adopted by Plato, Diogenes, Zeno, and by all of those who have won approval for their treatises on the subject ... (31.2)

Plutarch here ascribes to Lycurgus a principle of political perfectionism: the lawgiver should to try to make his political community as virtuous and unified as possible. He then says that that Lycurgus 'arranged and fitted together' ( $\sigma v v \varepsilon \dot{\tau} \alpha \xi_{\varepsilon}$

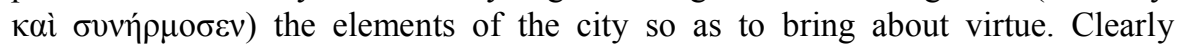
Plutarch's point is not restricted to the organisation of government but refers also to the distinctively Lycurgan social policies and institutions. It seems plain, therefore, that we should look beyond the 'form of government' in working out an understanding of Sparta as a template or model of Plato's ideal city. ${ }^{12}$ In the present context, the concept of ' $\pi$ o $\lambda \iota \tau \varepsilon i \alpha$ ' seems best understood as a 'regime' or 'a kind of

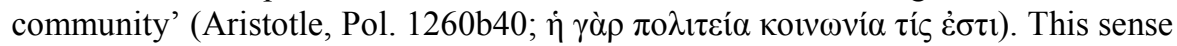
has the further advantage of fitting Plato's use of the term in the Republic, which has little to do with the organisation of government, and much to do with character of different kinds of political associations (Rep. 544d5 ff).

On the basis of the above discussion, Plutarch's meaning in the problematic attribution of the Spartan constitution to Plato is reasonably understood as follows: Plato adopted Lycurgus' Sparta as a template (vंró $\theta \varepsilon \sigma 1 \varsigma)$ in the construction of his ideal ' $\pi \mathrm{o} \lambda \imath \tau \varepsilon i$ ' $\alpha$ ' in the Republic, where the concept of ' $\pi \mathrm{o} \lambda \imath \varepsilon \varepsilon i \alpha$ ' includes both the form of government and socio-economic institutions. On this interpretation, possible similarities in regard to (say) civic institutions and social policies beyond

12 See also 'Plutarch's' discussion of the concept of ' $\pi \mathrm{o} \lambda \imath \tau \varepsilon i ́ \alpha$ ' in the probably spurious De unius in republica dominatione, 826-827. 
the 'form of government' might enable us to make sense of Plutarch's claim even if we do not accept it.

In the subsequent sections I offer an overview of the Spartan and Platonic regimes and then attempt a comparative analysis in an attempt to determine whether the above interpretation of Plutarch's claim about the structure of the Platonic and Spartan regimes can be accepted. The question of historical priority - whether Plato worked from a Spartan model, or whether Plutarch retrojects Platonic ideals onto the historical past - will not be considered in this paper.

\section{III}

The government of Lycurgan Sparta is comprised of three 'branches': kingship, gerousia, and assembly. ${ }^{13}$ Plutarch treats the ephorate as a later addition, albeit one deeply continuous with Lycurgus' constitutional reforms: 'the first ephors were appointed in the reign of Theopompus' about 'one hundred and thirty years after Lycurgus' (7.1).

According to Plutarch, Lycurgus preserved the Spartan dual kingship, but limited its power by creating a council of elders or gerousia (5.6). The creation of the council, which was composed of twenty-eight older men and the two kings (5.7), effectively reduced royal power to that of senators (5.6). Senators were formally equal to the kings qua senators, possessing an 'equal vote with them in matters of the highest importance' (5.6).

The powers of the council were exercised in the formulation of motions or rhetrai for presentation to the assembly (6.3-4). This power was later extended: the gerousia was granted to power of veto in the event of a 'crooked verdict' (6.4). But Plutarch holds that this right of veto was not itself part of the Lycurgan legislation. In the time of Lycurgus, the assembly of the people had 'the deciding voice and the power' (6.1-2).

Assignments to the dual kingship were hereditarily determined by membership of two ancient families, the Agiads and Eurypontids. By contrast, admission to the council was by election. Full Spartan candidates over the age of sixty years were elected by a vote of the assembly (26.1-4). Plutarch's description of the election (26.1-4) implies that, after the time of Lycurgus, elected members of the gerousia held office for life, a point which is confirmed by Aristotle

13 I will follow Plutarch's account of the Spartan regime, even when there are grounds for doubting its accuracy. Present concern is with Plutarch's understanding of the relation between Plato and Sparta. 
(Pol. 1270b35-40). Admission to the assembly was formally open to all Spartanborn males. ${ }^{14}$

The Spartan form of government is significant for whom it excludes. Both Spartan women and non-Spartans were excluded from the assembly. ${ }^{15}$ The nonSpartan inhabitants of Laconia and Messenia can be divided into two groups: helots and perioikoi. Plutarch says that Lycurgus did not enslave the helots; this was accomplished by Soüs (2.1), several generations prior to Lycurgus. Concerning the perioikoi, literally 'those who live around', Plutarch says only that they were included in the Lycurgan distribution of land (9.3). On the basis of independent evidence, it seems that they were 'free provincials' of semiautonomous towns and hamlets across Laconia and Messenia. ${ }^{16}$

Such in outline is the design of the Lycurgan government. If this governmental apparatus is considered in relation to hereditary Spartan adult males, it resembles a democracy. All 'Spartiates' had the right to participate in the assembly. However, when considered in relation to the population of Laconia and Messenia as a whole, it is best understood as an oligarchy of Spartans who ruled over a non-Spartan majority (cf. Powell 1998:101-103). ${ }^{17}$

IV

This section offers a brief overview of the 'economic' and 'social institutions' of Sparta. By economic, I refer to private property and occupation; by social institutions I refer to the family and education system.

Lycurgus divided the Laconian land equally amongst all Spartans (7.3). So the Spartan was a land-owner. And although Lycurgus' attempt to equalise 'movable' property failed, a general equality in the means of life was preserved by

14 Although Plutarch does not explicitly mention these points, the exercise of citizen rights also depended on graduation from the agoge and contribution to the dining halls. Material conditions of poverty therefore excluded some 'inferiors' ('hupomeiones') from full citizenship (cf. Xenophon, Hell. 3.3.4-11).

15 Spartan women had the right to occupy certain administrative positions of state, and to own land. On the latter point, Aristotle laments that women owned almost two-fifths of the entire country (Pol. 1270a20-25).

16 For more on the helots and perioikoi, see Cartledge 1979, ch. 10, and Powell 1988, chs. $4 \& 6$.

17 This is a point about the structure of government outlined in the Great Rhetra (Lyc. 6), and fully compatible with granting to certain groups and families disproportionate influence in actual political-decision making. See also n. 4 and the discussion in VIII below. 
economic regulation, in particular, the replacement of gold and silver with cumbersome iron currency (9.1-2).

The Spartan was a soldier by occupation. He lived as if in a 'military encampment' (24.1), being educated for war, educating for war, or engaged in war (24.1; cf. 22.1). His life was one of 'leisure', free from the concerns of production and money-making $(4.4 ; 24.2)$. The Spartan received his upkeep from the helots who 'tilled the ground' $(24.3 ; 8.3)$.

Spartan family structures were unusual by Greek standards. Marriages were open for the purpose of childbirth (15.6-8); children were regarded 'as the common property of the state' (15.8), 'not reared at the will of the father' but subjected to the examination of tribe elders at the Lesche (16.1). Lycurgus' 'most exquisite

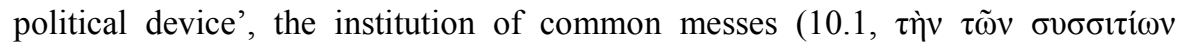

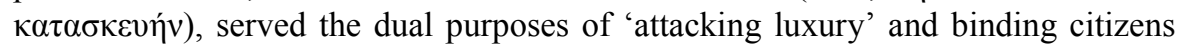
together in a common form of life $(10.1 ; 12.1)$.

Whereas the Spartans were 'artificers of war', 'slaves and aliens' took care of the mechanical arts and farming (Lyc.-Num 2.3). 'Slaves' must refer to the helots though the identity of 'aliens' is somewhat unclear. The helots did not own land; rather, they were bound to Spartan land as farmers and labourers, obliged to surrender to their masters more than half of what they produced in the fields (Lyc. 24.3; Powell 1988: 253). We are not to infer that the helots were restricted to farming; probably some of them were craftsmen and Plutarch refers elsewhere to the existence of helot nurses (Alc. 1.2; cf. Lyc. 16.3). But since the attachment of the helots to the soil is emphasised it is not unreasonable to think of them mainly as farmers. Plutarch does not have much to say about the helot mode of life. On the basis of independent sources, it appears that they were free to marry, have children, and run their households in the way that they thought best, at least within rather extreme conditions of poverty and subjugation (de Ste. Croix 1972:90)

The perioikoi are mentioned only once in the Lycurgus, in relation to the distribution of land (8.3). Since the perioikoi were land-owners their economic position was better than that of the helots (Powell 1988:251). 'By occupation many were smallholding farmers' (Sacks 1995:254), though tradition has it that a considerable number became artisans. This is a reasonable conclusion to draw, if the helots tilled the soil, and the Spartans were prohibited from the manual arts (cf. Cartledge 1979:157-158). They were not subject to significant restrictions in domestic life, which probably conformed to the patterns common in Hellenic culture.

According to Plutarch, Lycurgus' pre-eminence as a lawgiver is exhibited in his educational reforms (Lyc.-Num 4.2), in particular, the ' $\alpha \gamma \omega \gamma \eta$ '. The $\dot{\alpha} \gamma \omega \gamma \eta$ was designed to produce the qualities required for war (cf. Plato, Laws 625d-e). '[It] was calculated to make [Spartan youths] obey commands well, endure hardships, 
and conquer in battle' (16.6). Boys were 'taken by the state and enrolled in companies' (16.4) from the age of seven, and continued there in physical training and preparation for war until the 'years of full maturity' (24.1).

Although the major part of the education programme was focussed on physical toughness, Plutarch aims to show that Lycurgus did not neglect intellectual and spiritual qualities. He avers that Spartan education did not neglect music and poetry (21.1-4). And while reading and writing were taught at a fairly basic level (16.6), the character of the Spartan apothegms was such 'as to justify the remark that love of wisdom rather than love of bodily exercise was the special characteristic of a Spartan' (20.4). The use of apothegms in philosophical training is amply attested in the Hellenistic schools (Hadot 2002:244).

Such is what can be said, in outline, of the public schooling system in Sparta. But Lycurgus' concern with education went well beyond the $\dot{\alpha} \gamma \omega \gamma \eta$. This is evident in his concern with child-rearing from the time of earliest infancy (16.3) and his edification of the young women. Spartan girls were given opportunities for education and training not available to Greek women in general, and in fact, not to women of any nations until very recently: 'He made the maidens exercise their bodies in running, wrestling, casting the discus, [and] hurling the javelin...' (Lyc. 14.1-2). In a sense, the whole of Spartan public life was educational since it was designed to produce virtue. Plutarch says that the men of Sparta spent their days in the Leschai, 'chiefly occupied ... in praising some noble action or censuring some base one, with jesting and laughter which made the path to instruction and correction easy and natural' (25.1). This last point is especially applicable to the institution of the common meals, which were 'designed to make the citizen accept more fully the ideal which the laws expound and which constitutes the essential purpose of the state' (Morrow 1960:392). So important was education to the Spartan polity that Lycurgus assigned 'the function of lawmaking wholly and entirely to education' (13.2; cf. 13.3).

This completes my overview of the Spartan regime. In the next sections I will map out the main features of Plato's Republic in corresponding fashion, viz., the organisation of government, and primary social institutions and policies.

$V$

The governmental structure of Plato's republic is authoritarian. Political decisions are to be made by philosopher-kings without the participation of the citizen body. ${ }^{18}$ While Plato's design does not seem incompatible with a division of the

18 'All political decisions are made by the guardians without any reference to the citizen body’ (Taylor 1999, 281). 
philosopher-rulers into councils, the existence of specialised offices, and the use of certain sorts of voting procedures, the Republic does not offer any detail on how the rulers distribute the tasks of ruling.

'Plato's guardians are neither elected nor removable from office by popular vote' (Taylor 1999:281). Admission to the class of rulers is determined by age, education, and merit. ${ }^{19}$ Rulers are required to be over the age of fifty years and have passed through the full education programme. Socrates admits female guardians into the executive, a point explicitly made and argued for at length (454b-464b). Although the majority of denizens do not participate in government the office of philosopher-king is formally open: eligibility for office depends on merit and nothing else. The rulers are those who have 'survived the tests and are entirely best in every practical task and every science' (540a). A definition of a citizen as someone who is able to participate in government (cf. Aristotle Pol. 1275a) therefore implies, on a certain construal of 'can', that everyone living in the Kallipolis is a citizen. This latter point is in any case one that Socrates accepts: members of the productive class are explicitly said to be citizens of the polis (463a-b).

\section{$V I$}

As everyone knows, the Republic organises society into three classes of citizens: ruling, auxiliary, and productive. Class membership corresponds with occupation, which fixes other social characteristics such as property, wealth, and form of life.

The job is the most important determinant of social class. All those who are capable of ruling are to be guardians. Guardians 'will spend most of their time doing philosophy, but, when his turn comes, each must labour in politics and rule for the city's sake, not as something fine, but rather as something that must be done' (540b). ${ }^{20}$ No precise job description for auxiliaries is given. Roughly speaking, their function seems to overlap with that of the military and the police: protecting the polis from external enemies and ensuring civic law and order.

The economic and familial status of the rulers and the auxiliaries should be considered together: although they perform different jobs they share a common form of life. First, with regard to property and wealth, guardians and auxiliaries do not own land. They are permitted no private property 'that is not wholly necessary' (416d) and are strictly forbidden from touching or being 'under the same roof as' gold and silver (417a). Their necessities of life are covered by a

19 These are not independent variables. See e.g. 451e-452a on the relation between education and merit.

20 Translations of the Republic are by C D C Reeve 2004. 
stipend received from the productive class (415d-e; 543b-c). Guardians live communally without private rooms, taking their meals in common messes much 'like soldiers in a camp' (416e; cf. 464c). There are no nuclear families: women and children held 'in common' (449c, 423e4-424a2). This arrangement is intended to bind them together so that they treat all of their co-guardians as brothers and sisters, fathers and mothers, sons and daughters (463c). Marriage and breeding are regulated as part of a state eugenics program $(459 \mathrm{~d})$. There are special nurseries for guardian children $(460 \mathrm{~b}-\mathrm{d})$.

The third class of citizens is composed of artisans and farmers. Socrates does not say much about the socio-economic status of the producing class. What does seem clear is that members are permitted ownership of private property, money, and continue living in private families (see e.g. Rep. 421c ff.).

The social structure of the Kallipolis is unusual in its distribution of class characteristics. Unlike most real historical societies, the rulers and bearers of arms are prevented from owning property, live in material poverty, and without anything recognisable as a family life. On the other hand, those who are deprived of political rights and military power are permitted to hold property, accumulate a degree of wealth, and enjoy the pleasures of family life.

In the Republic, class is determined by job; and the allocation of jobs is fixed by merit within a framework of formal equality of opportunity. 'Every person must do one job for which he is naturally suited ...' (370c; italics added). ${ }^{21}$ Substantive equality of opportunity is secured by the education programme which fits people to jobs according to talent and other qualities relevant for success in their careers. ${ }^{22}$ Socrates regards the education system as the most important civic institution. The city's preservation depends on the preservation of the education program (423d-424c).

My discussion of education is focussed on the following questions: What is taught? And who is admitted? The guardian education programme is normally divided into two parts: elementary and advanced. Elementary education consists of music and literature, which begins with the stories mothers and nurses tell their children, along with elementary mathematics learned in a context of play (535a$537 b) .^{23}$ The elementary program is completed with two or three years of physical

21 This does not mean that people are by nature suited to one and only one occupation. Socrates' point is that a person cannot do more than one job well. Even assuming equality of natural ability and education, one must be in a position to do the required tasks at the appropriate times (370b).

22 Socrates' notorious Myth of the Metals indicates that class is to be determined by social role and social role by 'talent' $(414 \mathrm{c}-415 \mathrm{~d})$.

23 In addition, children are to be 'led into war on horseback as observers and ... wherever it is safe to do so, they should be brought close and taste blood, like puppies' (537a). 
training $(537 \mathrm{~b}-\mathrm{c})$. The advanced programme consists of 'ten years of education in the mathematical sciences' $(537 \mathrm{c}-\mathrm{d}, 522 \mathrm{c}-531 \mathrm{~d})$, five years of dialectic or philosophy (537d-540a, 531e-535a), and fifteen years of practical politics $(539 \mathrm{e}-$ 540a). Education is completed with the vision of the form of the good; only then are the apprentice guardians are ready to take charge of the city (540a).

The Republic's discussion of education is focussed on prospective guardians and gives little information on the training of craftsmen and producers. What can be said on this topic is that the children of craftsmen will likely learn the crafts of their parents (467a). ${ }^{24}$ We can assume that Socrates believes that artisans and farmers should be allowed to work out the best means for transmitting their knowledge to their children.

If the state is to ensure that jobs are assigned on the basis of merit, then everyone must receive appropriate education. Merit in the broad sense depends on education: natural talents and motives are shaped by training. This does not mean that everyone will get the same education. Rather, it means that the various kinds of schooling supported by the state are in principle open to everyone with the relevant qualities. This point is explicitly acknowledged by Socrates in the following exchange with Glaucon.

Is it possible, then, to employ an animal for the same tasks as another if you do not give it the same upbringing and education?

No, it is not.

Then if we employ women for the same tasks as men, they must also be taught the same things.

Yes.

Now, we gave the latter musical and physical training.

Yes.

So, we must also give these two crafts, as well as military training, to the women, and employ them in the same way. (451e-452a)

Given the principle of equality of opportunity as applied to schooling, children of craftsmen who display appropriate qualities will be shifted to the required education programme, and correspondingly, children of rulers without requisite aptitudes will be transferred to the productive class (415a-c).

24 See Reeve 1988:189-190. 
We are now in a position to analyse the relation between the Platonic and Lycurgan constitutions. I will begin with the primary socio-economic institutions and return to the question of governmental organisation.

The Republic makes provision for three kinds of jobs: ruler, soldier, and producer. The same three types of job occur in Sparta. But this is an insignificant point: tri-partitioning of a similar sort will occur in almost any city-state (cf. Aristotle, Pol. $1291 \mathrm{~b} 39$ ff.). More important is the distribution of jobs amongst the denizens of the polis.

In the Republic, a person does one and only one job; in Sparta, members of the producing class do only one type of job, but members of the ruling class do two: ruling and soldiering. This will be a 'concurrent' sense of 'doing' if power is located in the assembly; or 'consecutive' if in the council of elders: members of the gerousia require military experience but are not practicing soldiers. In either case, Sparta does not conform to Plato's 'one man, one job' principle. Moreover, even if the job descriptions of soldiers and producers were the same in the two regimes, the job requirements of the rulers are not. The rulers of the Kallipolis spend most of their time in philosophy (540b); this is not the case in Sparta where the ruling class is the military class. Although Plato's philosopher kings are brought up like soldiers, they rule over soldiers, and are not themselves soldiers. In the Republic, soldiers have no share in government.

The structure of the Kallipolis differs from Sparta not so much in the division of occupations as in the bases upon which people are assigned to their occupations. ${ }^{25}$ In the Republic people are assigned to jobs on the basis of merit, whereas in Sparta, selection by merit is circumscribed by considerations of birth and gender. ${ }^{26}$ Not the best person for the job; rather the best male, best Spartanborn male, etc. In Sparta, helots, perioikoi, and women cannot become full members of the Spartan government; in the Republic every individual is regarded as a potential philosopher-king. ${ }^{27}$

25 This may seem unfair to Plutarch since it goes beyond the scope of his discussion in the Lycurgus. Aside from a discussion of the qualifications required for election to the council (Lyc. 26), he does not specifically consider the question of how people come to be assigned to their social and economic positions within Spartan society. Nevertheless, the principle of job allocation by merit is so fundamental to the Platonic ideal state that it cannot be reasonably omitted from an account of its design.

26 See §III above on the economic requirements for citizenship.

27 This claim would need to be reformulated slightly if there is slavery in the Kallipolis. For discussion, see Vlastos 1973 and Reeve 1988. 
A second point of class comparison is property, 'immovable' or 'movable'. Neither the rulers nor the auxiliaries of the Kallipolis own any land or other private property. They have no money to speak of. This is not the case in Lycurgan Sparta. The Spartans own most of the Laconian land while the helots own none. And while the Spartan disdain for material goods is well known, their relative poverty is not offset - as it is in the Republic - with a corresponding gain in the material wellbeing of the helots. ${ }^{28}$

The third point of class comparison relates to the institution of the family. Since neither Plutarch in the Lycurgus, nor Plato in the Republic, has much to say about the lifestyle of the productive class, subsequent discussion will focus on the Spartan lifestyle in relation to that of Plato's two guardian classes. In Plato's ideal polity, the nuclear family is dissolved for the guardian classes. Breeding takes place at specially planned 'festivals' and so there are no marriages in any meaningful sense. Children do not even know their parents but are brought up by the state. Neither of these points applies to Spartans, even if the openness of Spartan marriages and state involvement in childrearing are unusual by Greek standards. In addition, with regard to living and eating, the Republic's two guardian classes live in common barracks. This does not seem true of the Spartiates, except perhaps in times of war. And although it appears that the institution of the dining-halls is common to both regimes, the respective arrangements differ on two key points. First, in the Kallipolis, but not Sparta the common messes are open to women (Rep. 458c-d); secondly, Spartans were required to contribute to their common meals individually, and could therefore lose their citizen status because of economic hardship. This is not the case in the Kallipolis where guardian upkeep is treated as a state expense (415d-e; 543b-c). ${ }^{29}$

Plutarch's account of Spartan schooling has some parallels with Plato's early education programme. One important point is that the education system is public and run by the state. In this respect, it differs much from Athens, where education was the responsibility of the private individual. Also, in regard to the qualifications for admission, it appears that although both Lycurgus and Plato are concerned with the education of women, Plato goes much further, granting to women the very same education as men, if, that is, they display the required capacities and motivations. By contrast, while Lycurgus requires that women take part in various kinds of gymnastic activities, they are excluded from the $\dot{\alpha} \gamma \omega \gamma \eta$. Moreover, the Republic's principle of specialisation implies that children of

28 Arguably, the restriction of the Spartans to the military art would have worked to the financial advantage of the perioikic craftsmen.

29 Compare Aristotle's discussion of the difference between the Spartan and Cretan common messes (Pol. 1272a12-27). 
producers are to be given access to guardian education, and indeed, the children of guardians to the education of producers, if they fail to display the necessary abilities for guardian schooling $(415 \mathrm{a}-\mathrm{c})$. There are no corresponding provisions in

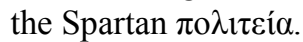

With regard to the content of education, the curriculum in both regimes incorporates music and poetry, reading and writing, and physical training. However, there seem to be significant differences in their respective higher education systems. In the Kallipolis, aspirant rulers engage in advanced mathematics, including arithmetic, plane geometry, solid geometry, mathematical astronomy, and harmonics, as preliminary to their five years training in dialectic (521d-533e). There is nothing akin to this in the Spartan education system even when the possible philosophical use of apothegms is recognised. Nor does the fifteen year apprenticeship in practical politics correspond with anything in the Lycurgan provisions (539e-540a). Plato's education system in the Republic cannot be plausibly construed as an extension of Spartan methods.

In summary, it seems reasonable to conclude that the social and economic organisation of the ideal state presented in the Republic can be regarded as an extension of the Spartan model. The Platonic and Lycurgan social systems converge on several important points: job specialisation, the tendency to gender equality, relative poverty of the ruling class, weakening of the nuclear family, and rigorous public education system. In each case, the Platonic institutions can be seen as idealised projections of ideals incipient in Plutarch's Lycurgus. These similarities — and inherent differences — can be accommodated by the interpretation that Plutarch conceives of Lycurgan Sparta as a template of Plato's social and political programme in the Republic.

\section{VIII}

The primary obstacle to acceptance of Plutarch's attribution of the Lycurgan constitution to Plato as template is the apparent discrepancy in governmental organisation. Sparta has a mixed constitution, combining elements of monarchy, oligarchy and democracy, whereas the Republic recommends an absolute aristocracy: government by the best people. Is there any way around this objection?

The Spartan government can be considered in relation to citizens, that is, hereditary male Spartans, or, in relation to all the people under the direct control of the Spartan executive. On the first option, Sparta appears to be a democracy. Although power is concentrated in the council of elders, twenty-eight of the thirty council-members are elected by the citizen body. Moreover, all citizens had the 
right to participate in the assembly, which exercised considerable control over the legislature and running of state: it had the 'deciding voice and the power' (6.1). ${ }^{30}$

Plato's Kallipolis is not a democracy in any sense at all. Members of the military and the producing classes are citizens of the polis, even though they have no share in ruling. If this is doubted in relation to the producers (Chroust 1965: 176), the exclusion of the auxiliaries from government should be enough to decide the point. The auxiliaries share a common form of life with the guardians and are clearly citizens. When the government of Sparta is considered in relation to the citizen body, there are no significant parallels between the Platonic and Lycurgan political institutions.

If the Spartan government is considered in relation to the non-citizen population of Laconia and Messenia as a whole, it is best understood as an oligarchy of Spartans who ruled over a non-Spartan majority (cf. Powell 1988: 102-103). Does this not offer a perspective from which Sparta and the Platonic republic share a governmental form? Both concentrate political power in one bloc: in Sparta, the 'equals' (hoi homoioi) rule non-citizen Spartans and helots (the perioikoi are better understood as being under Spartan suzerainty); in the Republic, philosopher-kings govern auxiliaries and producers. This will entail that the Spartiates are tantamount to philosopher-kings, an implication which seems to us absurd, but is perhaps intended by Plutarch, who regards Sparta as 'an entire city given to the love of wisdom' (31.2).

But this way of thinking of the relation between the government and the governed is unsatisfactory. If the ruling class is considered in relation to noncitizens, even Athens will be analysed as an authoritarian state: women, noncitizen residents and slaves had no share in the running of the city. This consequence may be acceptable in some contexts, such as those where the limitations of Athenian democracy are in question; but not the present one. If the criterion by which Sparta and Plato's republic share a common form of government is one which implies that Athens and the Kallipolis are both totalitarian states, something has gone wrong with the reasoning. The basic point is surely that in Athens and Sparta, all citizens have a share in government, whereas in the Republic, not all do.

The governmental organisation of Plato's republic is different from that of Sparta. In addition, it is hard to understand how Plato's ideal state could be regarded as an extension of a Spartan core. The difference between a mixed

30 The fact that Sparta tried to establish oligarchies in states under her control does not alter the basic fact: the Spartan constitution has a significant democratic element. See note 4 and Powell 1988:101-103. 
constitution and a pure aristocracy is not a difference of degree: they are two fundamentally incompatible governmental forms.

$I X$

In its economic and social organisation, Plutarch's representation of Sparta does correspond with elements in the republic of Plato. Although the relation between the two regimes is not one of identity, the Platonic republic can be understood as an extension and idealisation of Plutarch's Lycurgan Sparta. This is a point about socio-economic structure and does not imply that Plutarch's attribution is credible in regard to the actual origination of Plato's ideal city. On the other hand, the authoritarian design of the Platonic republic seems difficult or even impossible to square with the democratic aspects of the Spartan polis. Short of pursuing the second strategy of reconciliation outlined in $\$ 1$ above, viz. a rhetorical justification, perhaps the only thing that can be said on Plutarch's behalf is that he regards the socio-economic organisation of the state as considerably more important than the formal structure of government; and that this latter is anyway a concept alien to ancient political thought. ${ }^{31}$

\section{BIBLIOGRAPHY}

Aristotle 1941. Politics. In McKeon, R (ed.), Basic works of Aristotle, 1127-1324. New York: Random House.

Aalders, G J D 1982. Plutarch's political thought. New York: North-Holland Publishers.

Bobonich, C 2002. Plato's Utopia recast: His later ethics and politics. Oxford: OUP.

Brown, E 2009. Ethics and politics in Plato's Republic. In Zalta, E Z (ed.), Stanford Encyclopedia of Philosophy.

http://plato.stanford.edu/entries/plato-ethics-politics/

Buckley, T 2010. Aspects of Greek history: A source-based approach. $2^{\text {nd }}$ edition. London: Routledge.

Burnyeat, M F 1999. Culture and value in Plato's Republic. The Tanner lectures on human values. Salt Lake City: University of Utah Press.

Cartledge, P 1979. Sparta and Lakonia: A regional history, 1300-362 BC. London; Boston: Routledge \& Kegan Paul.

31 I would like to express my gratitude to Sjarlene Thom and an anonymous referee for their help in improving this paper. 
Chroust, A H 1965. The ideal polity of the early Stoics: Zeno's Republic. The Review of Politics 27.2:173-183.

De Ste. Croix, G E M 1972. The origins of the Peloponnesian War. Ithaca, NY, Cornell University Press.

Harrison, S, Lane, M, Rowe, C, \& Schofield, M 2000. The Cambridge history of Greek and Roman political thought, Cambridge: Cambridge University Press.

Laks, A 1990. Legislation and demiurgy: On the relationship between Plato's Republic and Laws. Classical Antiquity 9.2:209-229.

Liebert, H 2009. Plutarch's critique of Plato's best regime. History of Political Thought 30.2:251-271.

Moles, J 2000. The Cynics. In Harrison, S et al (eds.), The Cambridge history of Greek and Roman political thought, 415-434. Cambridge: Cambridge University Press.

Moore, K R 2011. Plato, politics and a practical utopia: Social constructivism and civic planning in the Laws. London: Continuum.

Morrow, G R 1960. Plato's Cretan city: A historical interpretation of the Laws. Princeton University Press.

Plato 2004. Republic. Trans. C D C Reeve. Indianapolis: Hackett.

Powell, A 1988. Athens and Sparta. London: Routledge.

Plutarch 1914. Lives. Vol. 1. Trans. B Perrin. Cambridge, MA: Harvard.

Plutarch 1927. Moralia. Vol. 10. Trans. H N Fowler. Cambridge, MA: Harvard.

Reeve, C D C 1988. Philosopher-kings: The argument of Plato's Republic. Indianapolis: Hackett.

Sacks, D O, Murray, O, \& Burnson, M 2009. Encyclopedia of the Ancient Greek World, Infobase Publishing.

Schofield, M 2000. Epicurean and Stoic political thought. In Harrison, S et al (eds.), The Cambridge history of Greek and Roman political thought, 435456. Cambridge: Cambridge University Press.

Thucydides 1972. History of the Peloponnesian War. Warner trans. Harmondsworth, Eng.; Baltimore, Penguin Books.

Tigerstedt, E N 1974. The legend of Sparta in Classical Antiquity. Vol. 2. Stockholm: Almqvist \& Wiksell.

Wardman, A 1974. Plutarch's Lives. London: Paul Elek. 